مدلسازى رويشخاه بالقوه گونه كما Ferula ovina (Boiss) با استفاده از مدل خطى تعميم يافته

$$
\text { مهسا قاضى مرادى'، مصطفى تركش '* و حسين بشرى' (GLM) }
$$

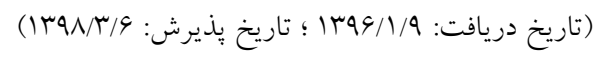

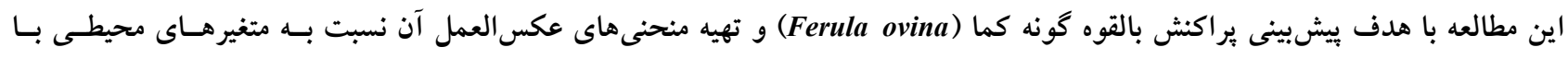

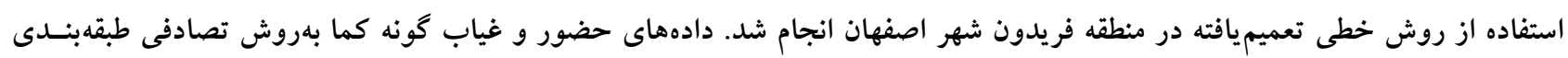

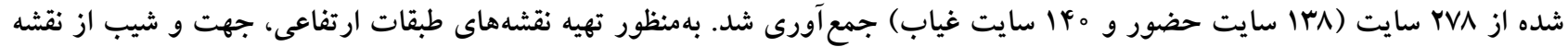

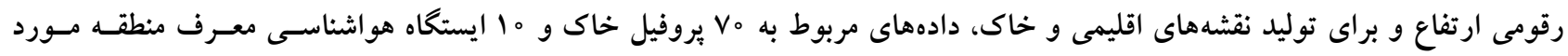

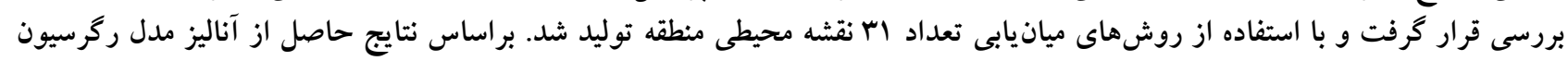

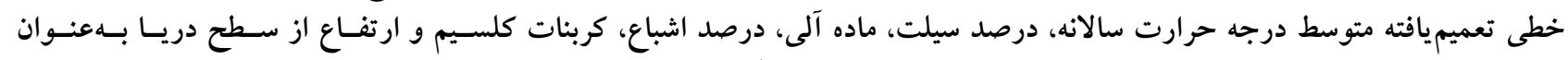

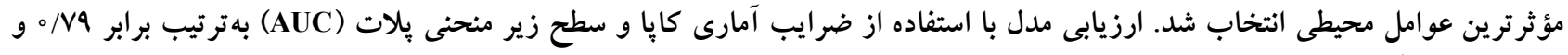

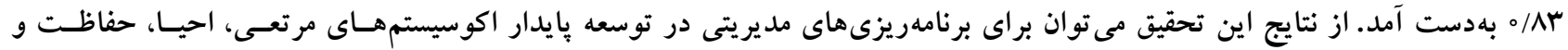

وازههاى كليدى: سيستم اطلاعات جغر افيايى، ميانيابى، مدل ير اكنش گونهاى، منحنى عكس العمل گونهاى 
مكانى گونههاى گياهى دارند و ضمن تهيه نقشه رويشـاه بـالقوه

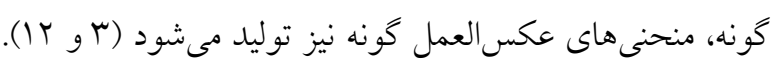

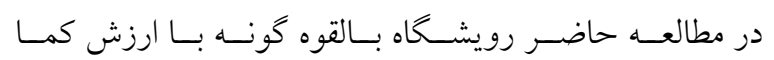

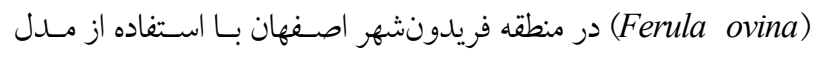
خطى تعميميافته بررسى شده است. هدف ديخر ايسن مطالعـه ترسـيم

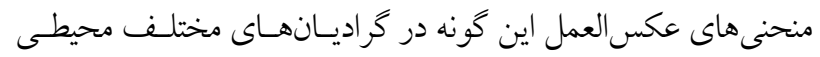

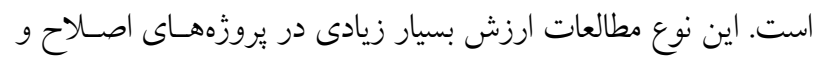

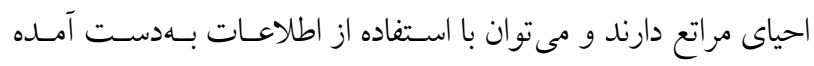
مناطق مناسب احياى اين گونههاى گياهى را تعيين كرد ( آ و YT).

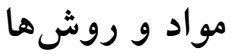
منطقه مورد مطالعه

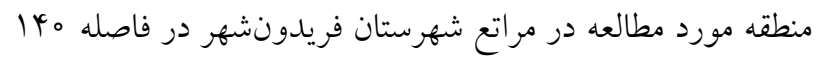

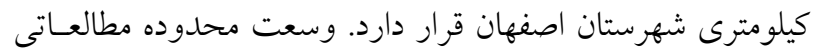

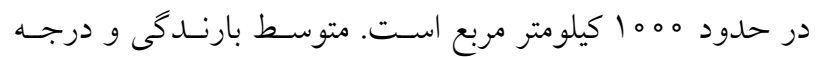

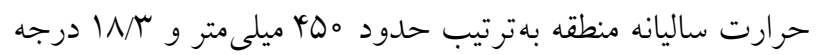

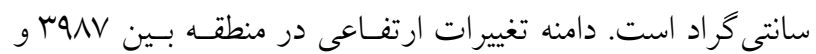

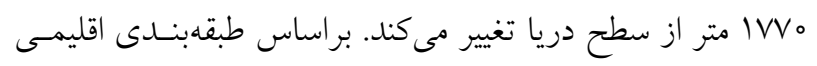

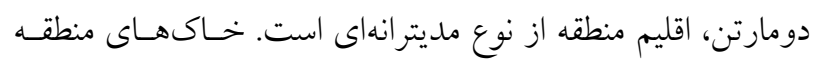

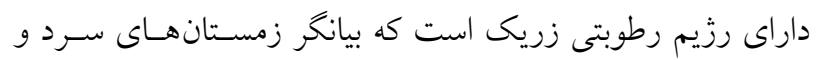

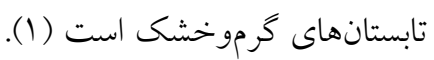

\section{كونه مورد مطالعه و جمع آورى دادههاى رخداد}

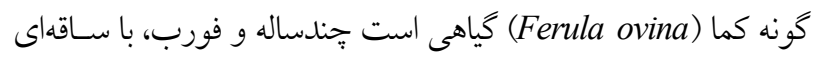

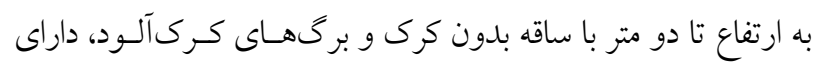

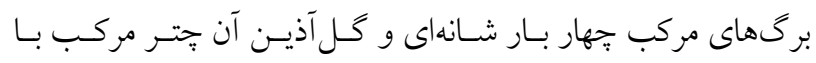

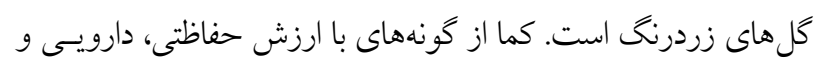

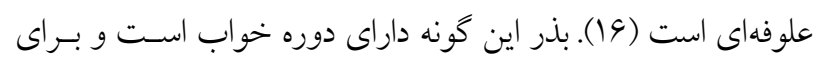

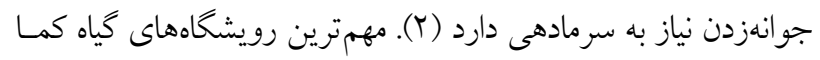

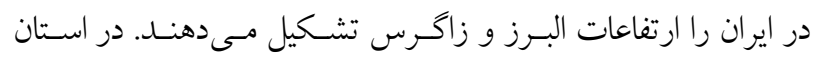

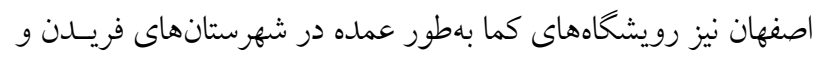

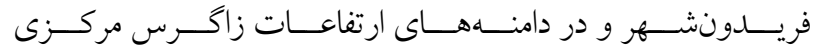

امروزه در عرصه اكولوزى كياهى، تهيه نقشه هـيشبينى يـراكنش

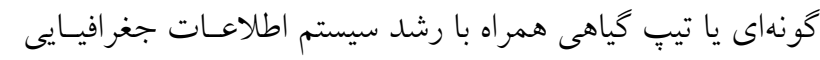

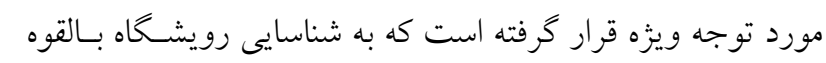

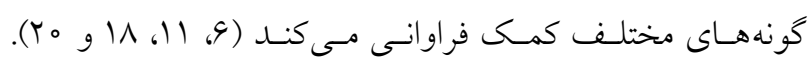

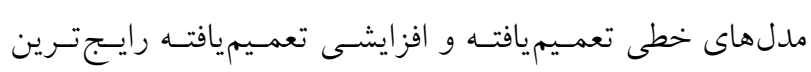

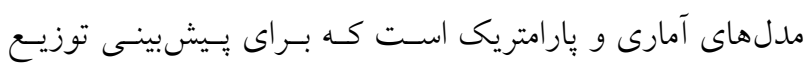

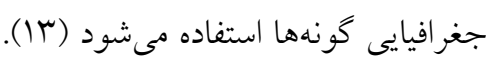

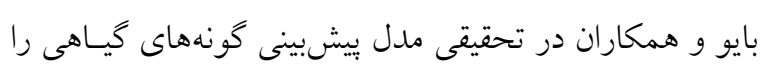

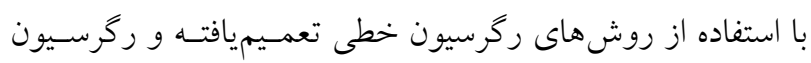

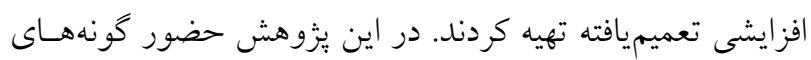

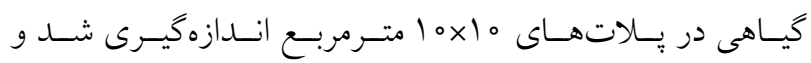

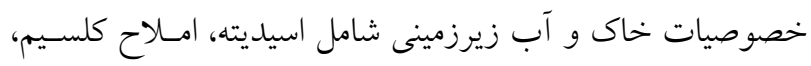

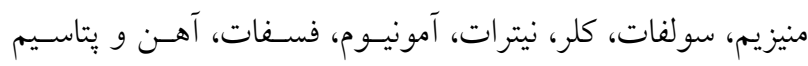

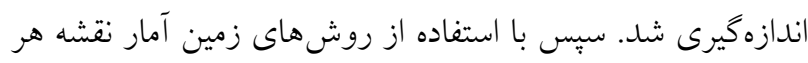

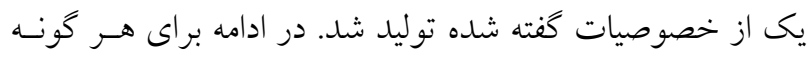

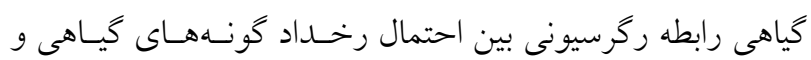
خصوصيات محيطى تعيين و بعد از تعميم رابطه رياضسى بـه كـل منطقه، نقشه احتمال حضور براى گونهاى كياهى تهيـه شــ (V).

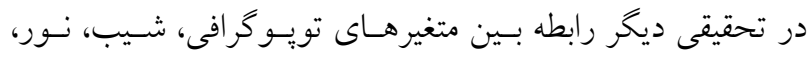

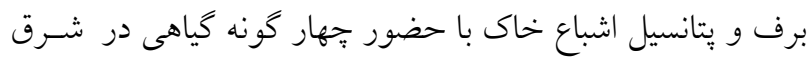

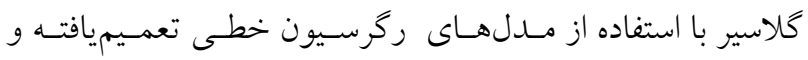

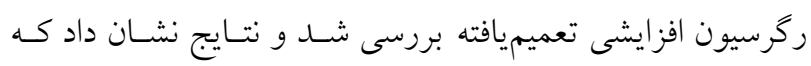

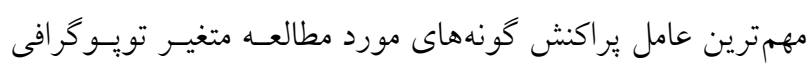

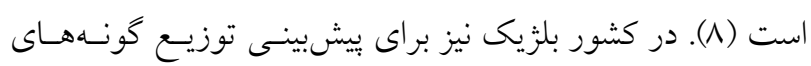

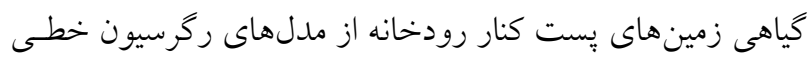

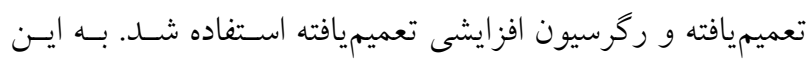

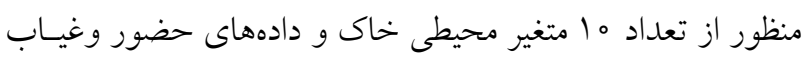

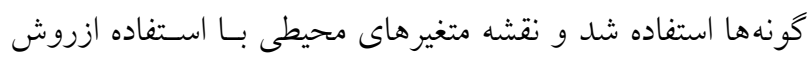

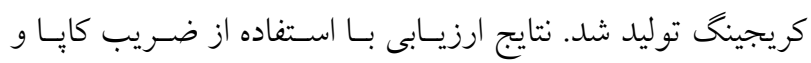

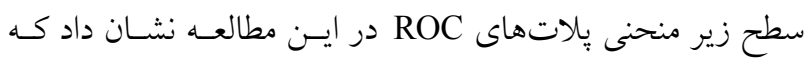

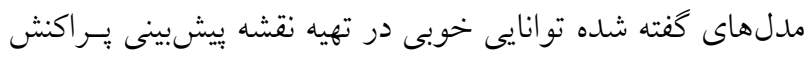


جدول ا. ليست متغيرهاى اقليمى خاك و فيزيوگر افى براى بيشبينى رويشخاه بالقوه كونه كما

\begin{tabular}{|c|c|c|c|c|c|}
\hline و واحد & علامت & 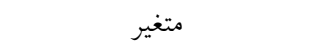 & واحد & علامت & 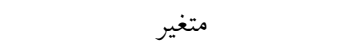 \\
\hline ميلى متر & P.war.q & بارندگى در گرمترين فصل & درجه سانتى گراد & Min.c.q & حداقل دما در سردترين فصل \\
\hline- & $\mathrm{pH}$ & و اكنش خاى & درجه سانتى گراد & T.wet.q & متوسط دما در مرطوبترين فصل \\
\hline لمرصد & $\mathrm{OM}$ & 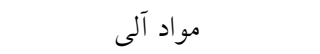 & درجه سانتى گراد & T.D.Q & متوسط دما در خشكترين فصل \\
\hline درصد & $\mathrm{OC}$ & 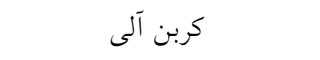 & درجه سانتى گراد & T.war.Q & متوسط دما در گرمترين فصل \\
\hline ميلى متر & P.c.q & بارندگى سردترين فصل & درجه سانتى گراد & T.C.Q & متوسط دما در سردترين فصل \\
\hline 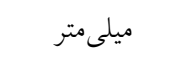 & P.s & 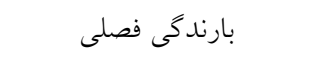 & ميلى متر & A.m.p & ميانخين بارش سالانه \\
\hline درجه سانتى گراد & T.s & درجه حرارت فصلى & ل مرصد & SP & رطوبت اشباع \\
\hline درجه سانتى گراد & T.r & دامنهى درجه حرارت سالانه & م ت مرصد & Clay & 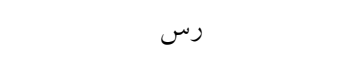 \\
\hline درجه سانتى گراد & D.m.t & ميانخين دماى روزانه & لم ت مرصد & Silt & سيلت \\
\hline درجه سانتى گراد & A.m.t & ميانغين دماى سالانه & درجه سانتى گراد & Isotherm & مناطق همبدما \\
\hline درصد & $\mathrm{CaCO}_{3}$ & 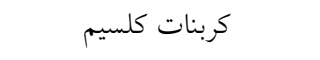 & ميلى متر & P.d.m & بارندىى در خشكترين ماه \\
\hline درصد & Slope & شيب & 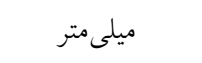 & P.wet.q & بارندكى در مرطوبترين ماه \\
\hline \multirow[t]{2}{*}{ متر } & DEM & 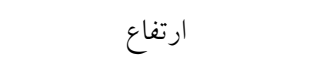 & ميلى متر & P.d.q & بارندگى در خشكترين فصل \\
\hline & & & ميلى متر & P.wat.q & بارندگى در مرطوبترين فصل \\
\hline
\end{tabular}

\section{نقشه هاى محيطى}

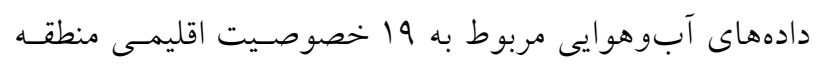

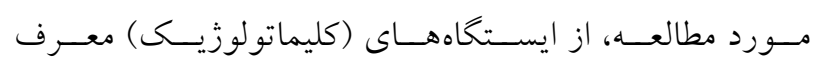

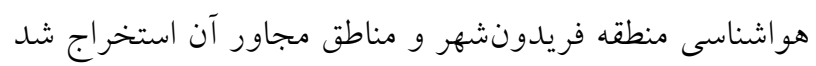

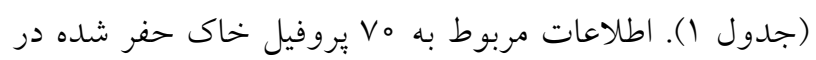

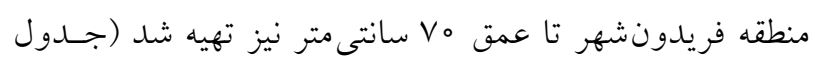

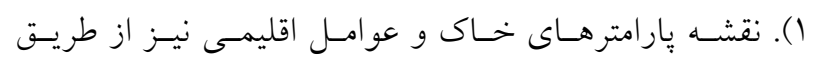
روش هاى مختلف ميان يابى تهيه شد. بدين منظور ابتــا نرمـال

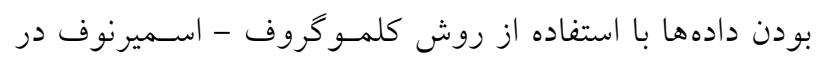

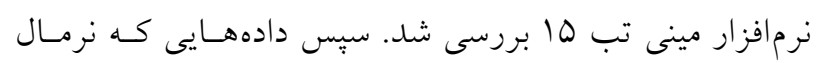

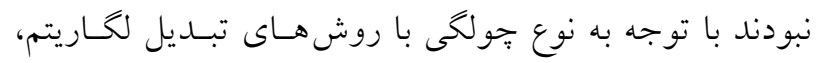

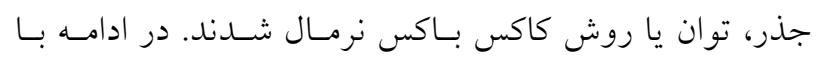

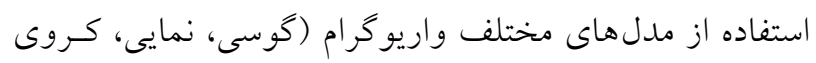

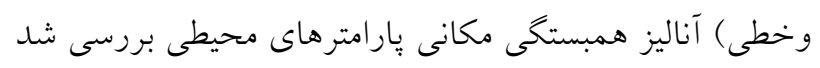

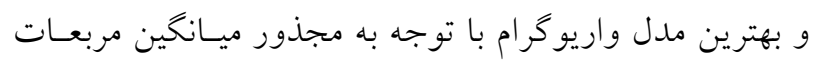

واقع شده است (ه). بـهمنظـور جمـع آورى دادههـاى حضـور و

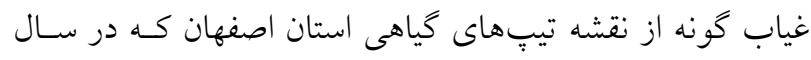

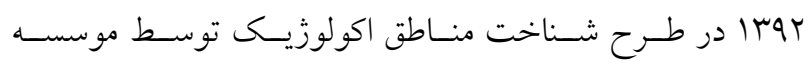

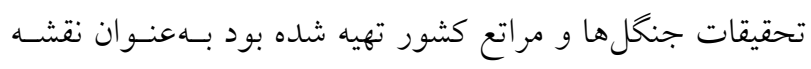

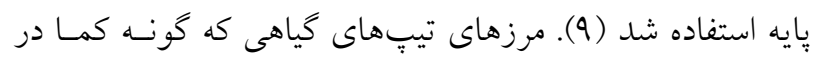

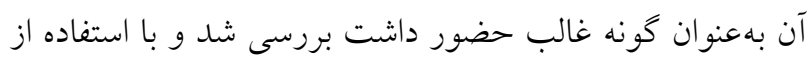
روش نمونهبردارى تصادفى طبقهبندى و سايت هـاى حضـور و

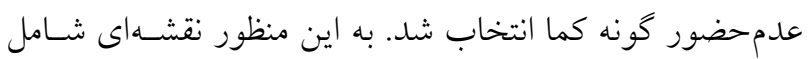

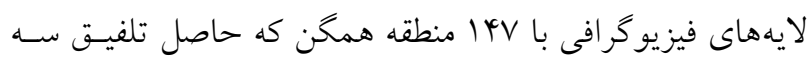
طبقه ارتفاعى، شش طبقه شيب و 9 طبقه جهت است، تهيه شد.

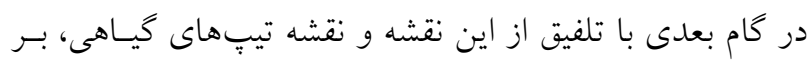

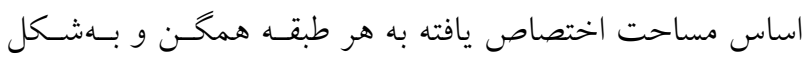

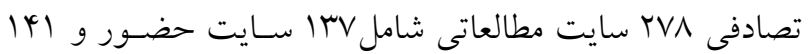
سايت عدم حضور مشخص شد كه صحت نقاط ذكـر شــده بـاـ بازديد صحر ايى تأييد شد. 
متفاوت است. بهطور عمده دو روش براى ارزيابى مدل وجود

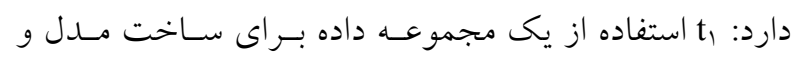

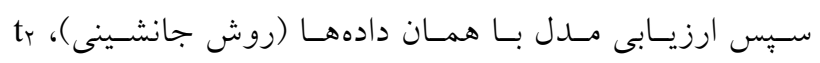

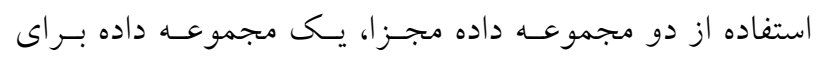

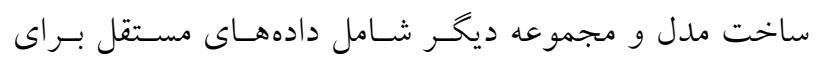

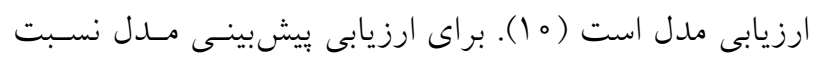

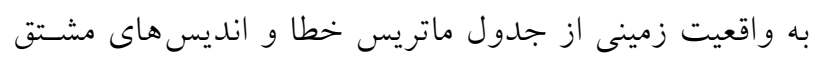

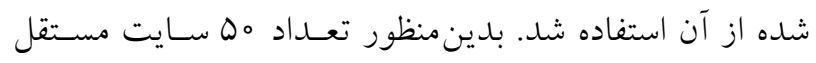

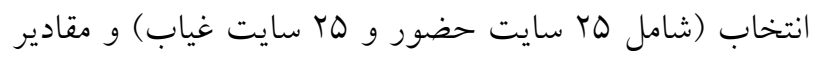

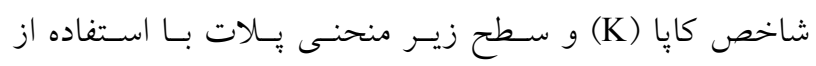

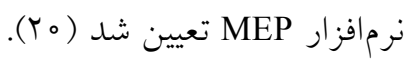

\section{نتايج}

مدل واريوگرام

براى هر متغير محيطى بر اساس مقادير مجذور ميانكين مربعات

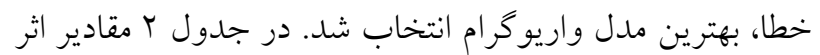

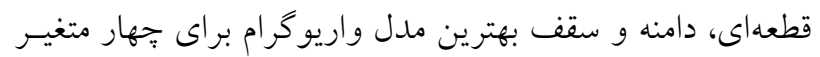

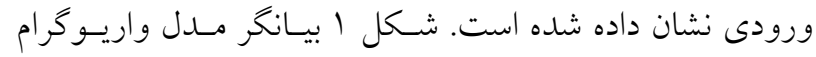

$$
\text { نمايى درصد سيلت است. }
$$

توليد نقشه هاى محيطى بــا اسـتفاده از روش هـاى ميـانيـابى

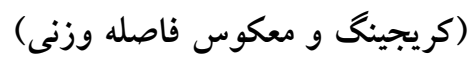

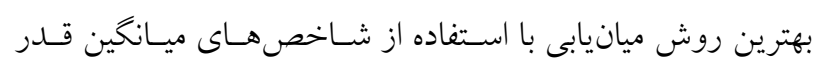

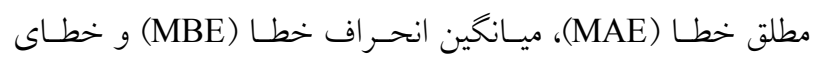

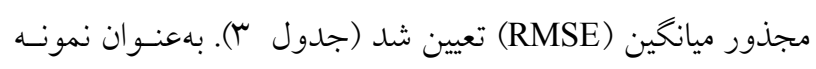

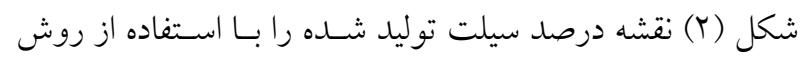

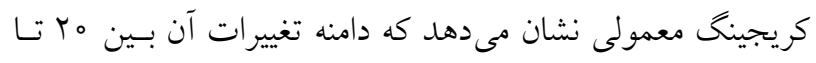
أب و درصد است.

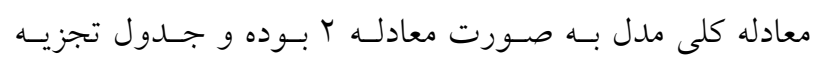
واريانس آن در جدول شماره ب آورده شده است.

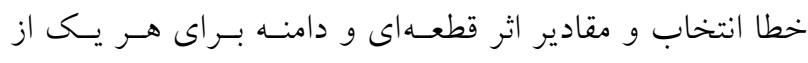

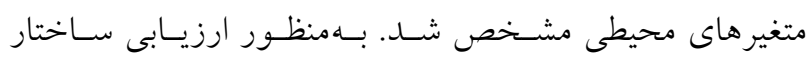

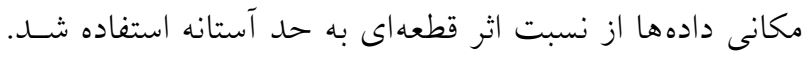

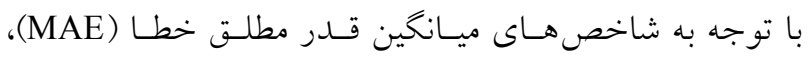

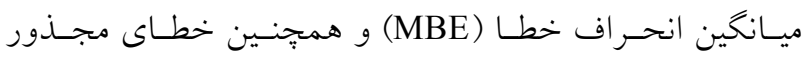
ميانخين (RMSE) بهترين روش ميانيابى براى هر متغير تعيين

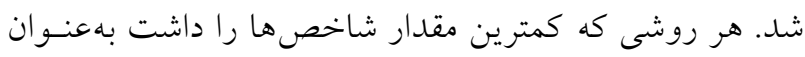

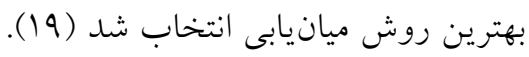

مدل رگرسيون خطى تعميم يافته

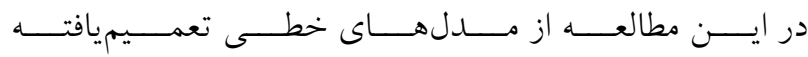
براى بيشبينى توزيـع (Generalized Linear Model = GLM)

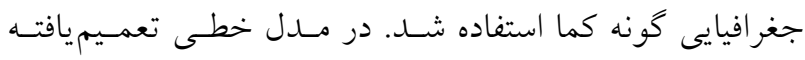
مشكلات مربوط به متغيرهاى وابسته بهوسيله تبـديلات منطقى هم:جون تبديل لكماريتمى برطرف مسى شـود و پِارامترهـاى مـدل

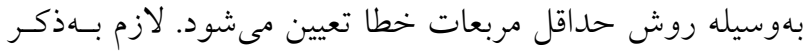

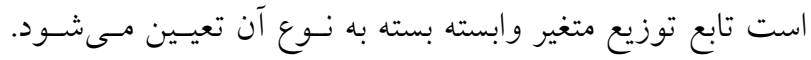
جنانجه متغير وابسته شمارشى باشد از توزيع يواسـون و اخـــ از

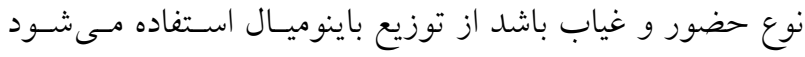

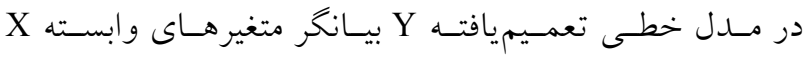

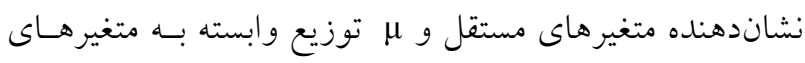
مستقل را نشان مىدهد (معادله ():

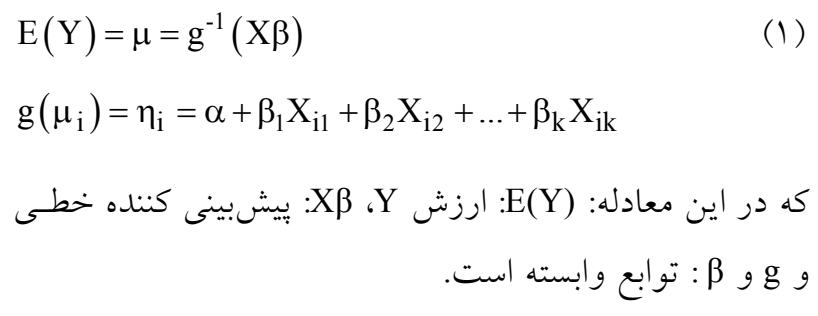
ارزيابى مدل برحسـب هـــف مطالعـه و كـاربرد مــدل نـوع روش ارزيـابى مدر

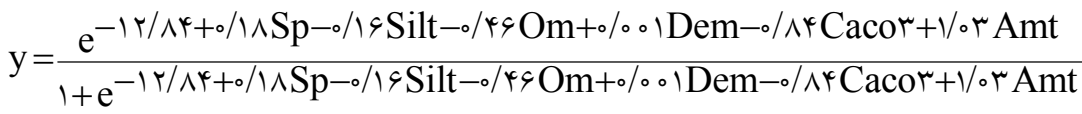


جدول r. اجزاى مربوط به واريوگرام متغيرهاى وارد شده به مدل

\begin{tabular}{|c|c|c|c|c|c|c|}
\hline RMSE & كلاس وابستخى & $\mathrm{C} 0 /(\mathrm{C}+\mathrm{C} 0)$ & آستانه (C+C0) & اثرقطعهاى (C0) & مدل تغييرنما & بارامتر \\
\hline $9 / N$ & متوسط & $0 / 44$ & $V 0 / 99$ & 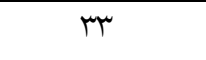 & نمايى & سيلت \\
\hline $1 / 1 \pi$ & قوى & $0 / 09$ & $T / 19$ & $0 / r_{0}$ & 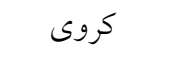 & كربنات كلسيم \\
\hline $9 / 48$ & قوى & $0 / T r$ & $10 N / 1$ & $Y Y / \Delta$ & نمايى & درصد اشباع \\
\hline $0 / 99$ & قوى & $\circ / 0 \Delta 9$ & $N / 91$ & $\circ / 0 \circ$ & كوسين & ميانكين درجه حرارت ساليانه \\
\hline
\end{tabular}

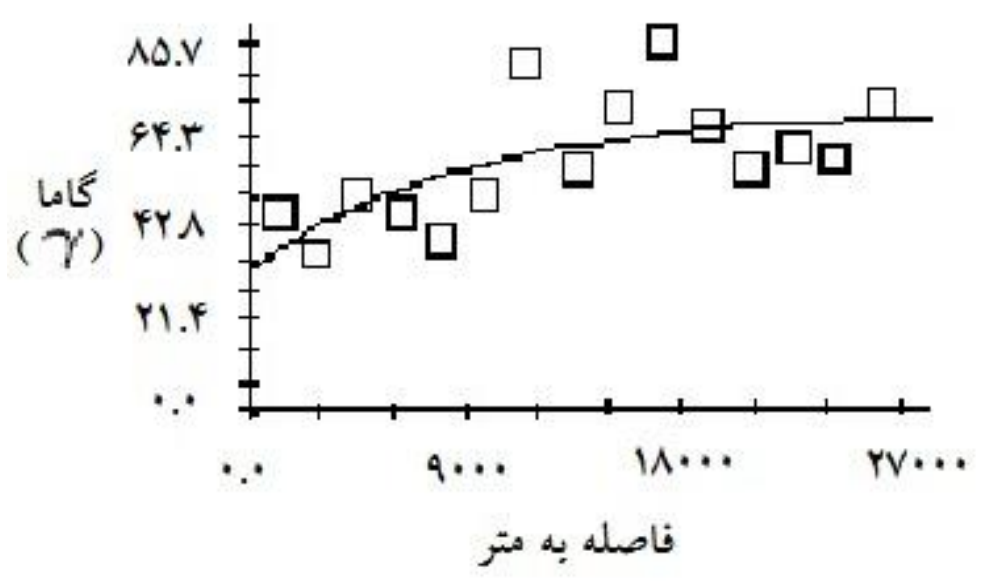

شكل 1. مدل واريوگرام توليد شده درصد سيلت.

جدول r. بهترين مدل ميانيابى انتخاب شده براى تهيه نقشه متغيرهاى محيطى مانك

\begin{tabular}{|c|c|c|c|c|}
\hline خطاى مجذور ميانكين & ميانگين انحراف خطا & ميانخين قدر مطلق خطا & روش ميانيابى & متغير \\
\hline $9 / N$ & $-0 / \pi q$ & $\Delta / r$ & ساده & سيلت \\
\hline $1 / 79$ & $0 / r$ &.$/ 94$ & معكوس فاصله وزنى & ماده آلى \\
\hline $1 / 14$ & $\circ / \circ r^{2}$ & $\circ / 11$ & 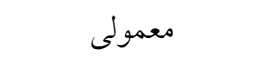 & كربنات كلسيم \\
\hline$\circ / N$ & -o/०r & $\circ / 09$ & 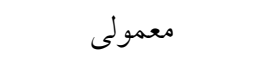 & درصد اشباع \\
\hline$\circ / 99$ & $-0 / 01 \wedge$ &.$/ 9 \mathrm{~V}$ & 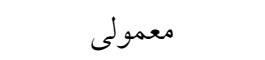 & ميانكين درجه حرارت ساليانه \\
\hline
\end{tabular}

طبق نقشه بيشبينى براكنش رويشـاه كونسه، مسـاحت طبقـهـ

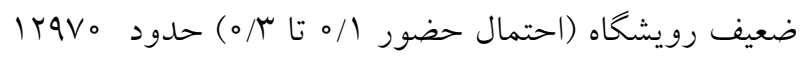
هكتار سا درصد كل منطقه و طبقه متوسط رويشكاه (احتمـال (احتمال

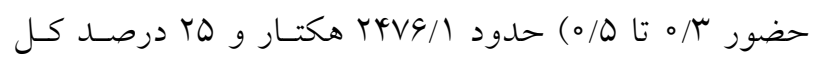

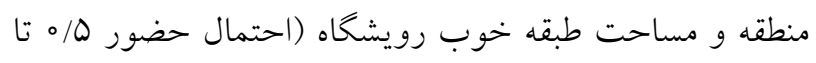

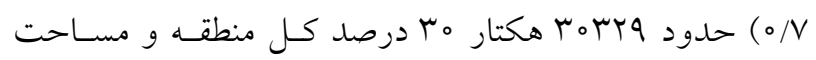

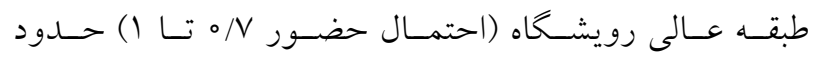
II IV/T
نقشه بير اكنش گونه كما

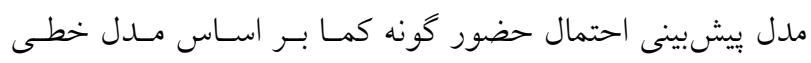

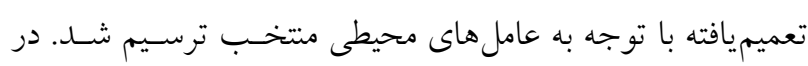

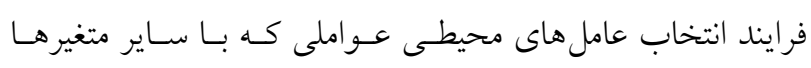

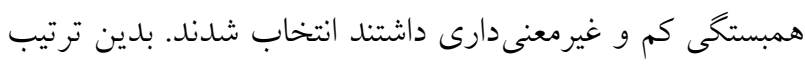
از الب عامل محيطى مطالعه شده، جهار متغير خـاك (ميـزان مـاده

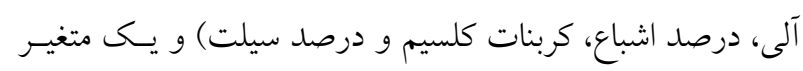

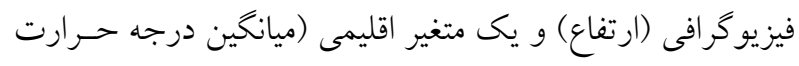

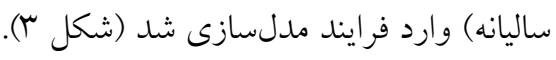


بومشناسى كاربردى/ سال هشتم / شماره اول / بهار 19r|

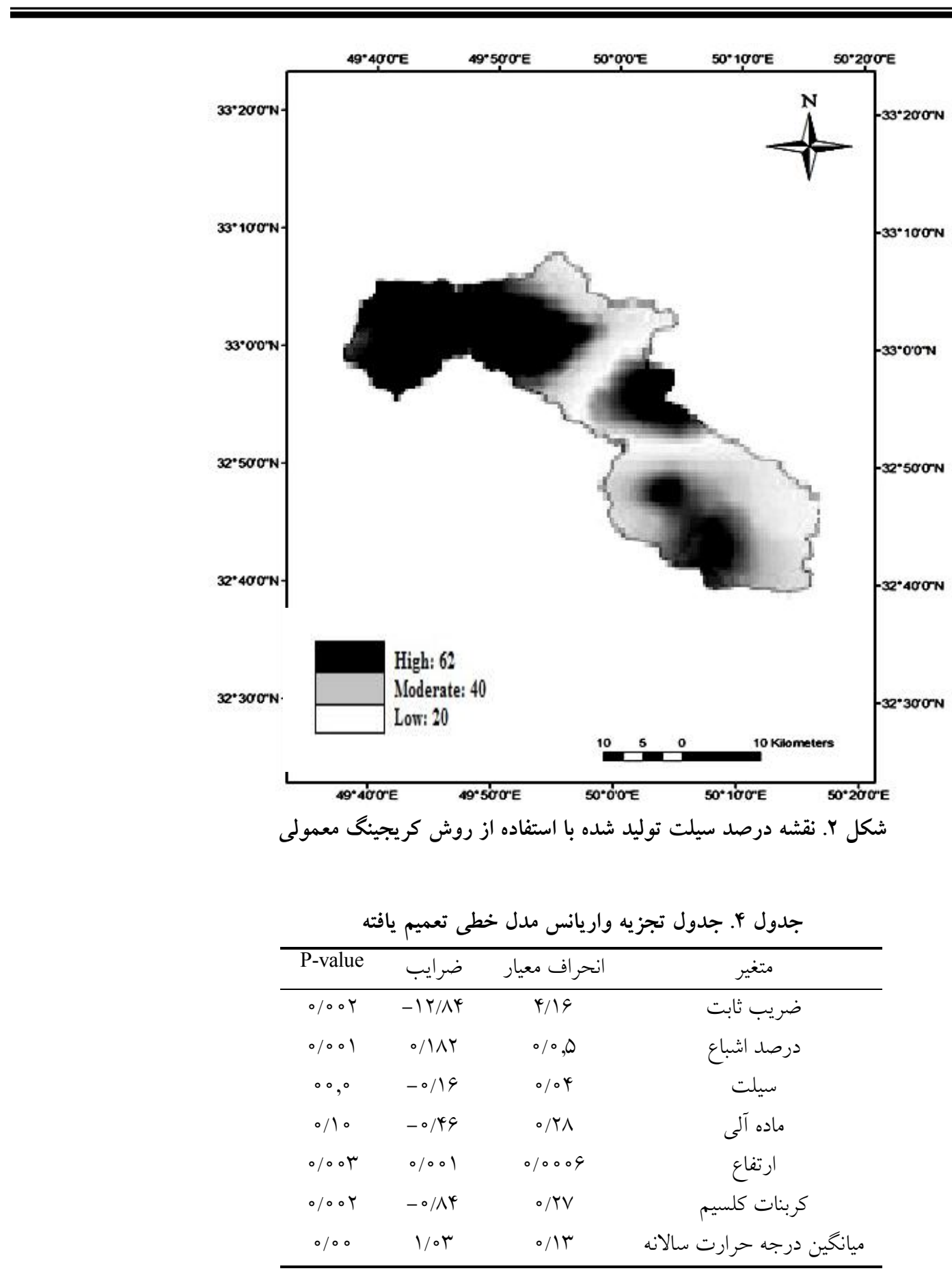

واقعيت زمينى نشان داد. نتايج ارزيابى با اسـتفاده از دادههـاى ارزيابى مدل رگرسيون خطى تعميميافته مستقل و ماتريس خطا نيز نشان داد كه بر اسـاس طبقـهبنـدى

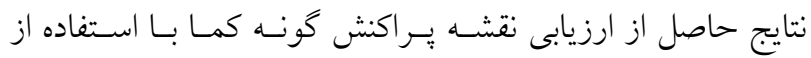

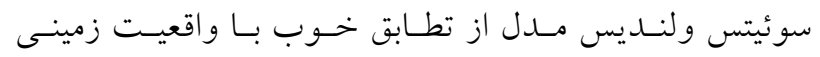

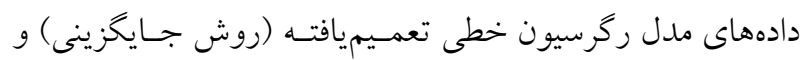
ماتريس خطا نشان داد كه مدل يـيشبينـى شــه داراى مقـدار برخوردار است (جدول ه). همانطور كه در جــدول مشـخص است سلول اول بيانخر 19 مشاهده حضور كونه كمـا در دنيـاى ضريب كاياى /V9/ و تطابق خوب است. همخِنين روش سطح واقعى است كه مدل نيز توانسته اسـت آنـرا بدرسـتى بـهنــوان زير منحنى پيلات (AUC) با مقدار سم/ه تطابق قابـل قبـول بـا 


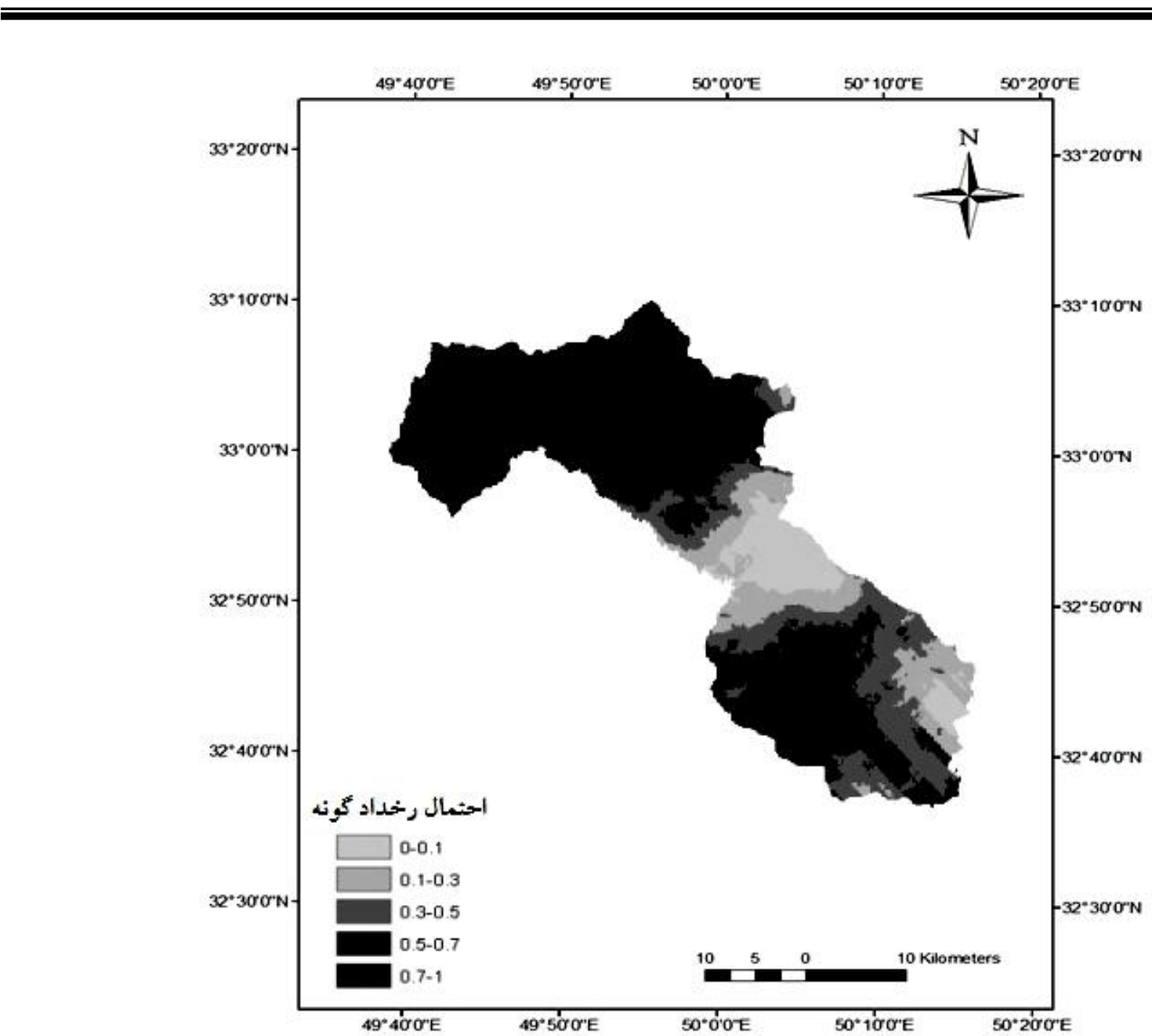

شكل r. نقشه بيشبينى براكنش رويشگاه گونه كما (Ferula ovina) در منطقه مطالعاتى فريدونشهر اصفهان

جدول هـ ماتريس خطاى حاصل از ارزيابى مدل GLM با استفاده از روش مستقل و جايكزينى

\begin{tabular}{|c|c|c|c|c|}
\hline \multicolumn{2}{|c|}{ ارزيابى با استفاده از روش جايخزينى } & \multicolumn{2}{|c|}{ ارزيابى با استفاده از روش مستقل } & \\
\hline 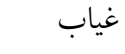 & حضور & 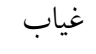 & حضور & \\
\hline rq & 110 & r & 19 & حضور مشاهده شده در واقعيت زمينى \\
\hline TV & 110 & rt & 9 & غياب مشاهده شده در واقعيت زمينى \\
\hline
\end{tabular}

متغيرهاى متوسط درجه حرارت سالانه، درصد سيلت، ميزان مـاده

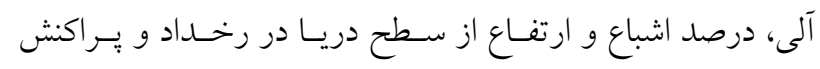
كونه كما تأثير بسزايى دارند. حضور كونه كما با ميزان سـيلت در منطقه مطالعاتى داراى روند تقريباً معكوس است يعنى با افـزايش

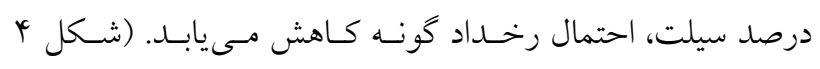
قسمت ب). رخداد گونه با ارتفاع از سطح دريا، ميزان مـاده آلى، دري،
حضور بيشبينى كند ولى عدد ب بيانگر تعداد مشـاهده حضـور كونه در دنياى واقعى است كه توسط مدل بهعنوان غياب درنظر كرفته شده است. تتايج اين تحقيق نشان داد از بين عاملهاى محيطى مورد بررسىى، 


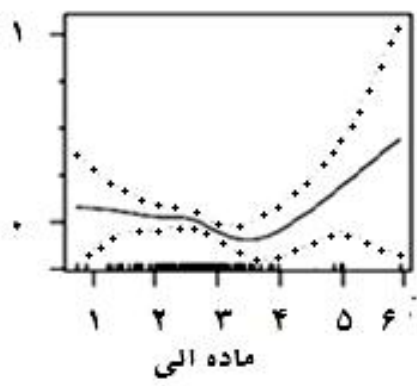

(الف)

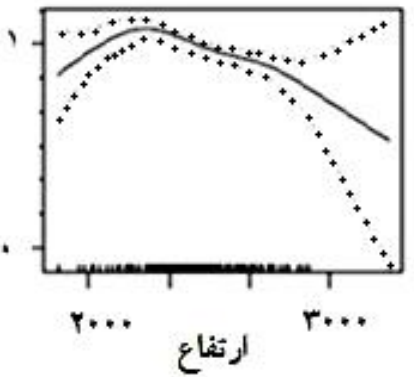

(2)

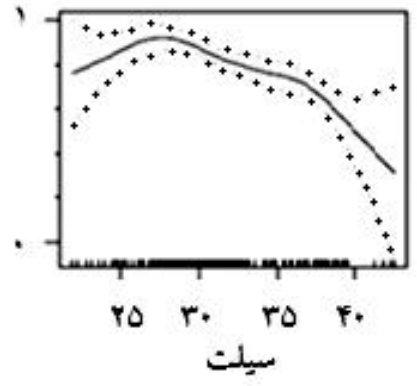

(ب)

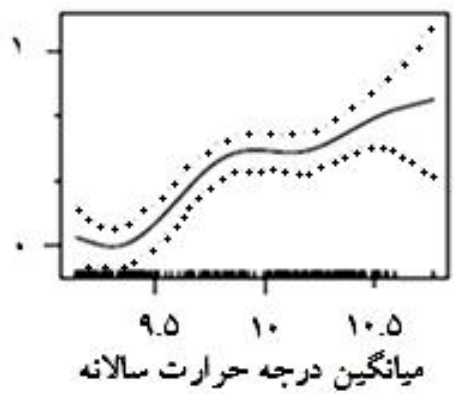

(o)

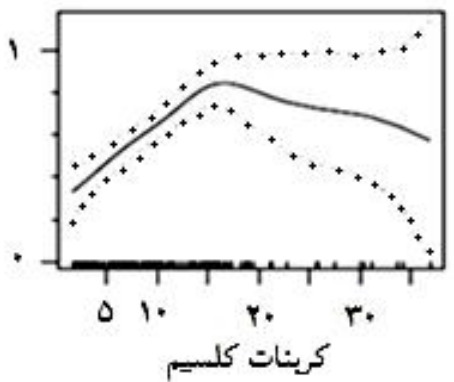

(ج)

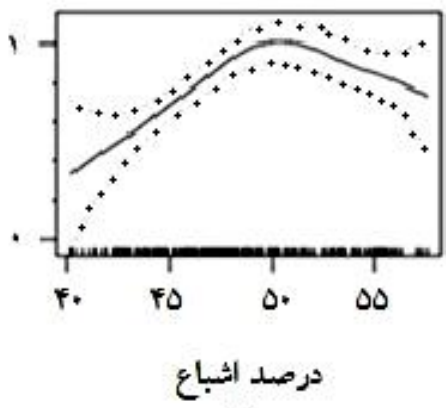

(g)

شكل f. منحنى عكس العمل متغيرهاى محيطى (اقليمى، خاك و فيز يوگرافى) مورد مطالعه (خطوط خطجين نشاندهنده فاصله اطمينان و خط ممتد نشاندهنده تغييرات متغير محيطى نسبت به حضور و غياب گونه مذكور است)

عوامل مؤثر بركونه كما در منطقه وهرگـان اسـتان اصـفهان بافـت خاك، جهت شيب و شاخص رطـوبتى بـوده اسـت و ايسن كونـه عمدتاً جهتهــاى شـمالى و شـرقى كـهـ بافـت سـنكين دارنــ را

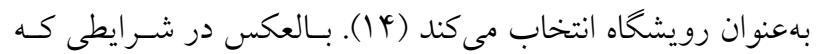
خاى مناسب بوده و عمق خاك زياد باشــ گونسه كمـا سـريع در رقابت با ساير كونهها شكست مى خورد زيرا اين گياه مواد غذايى مورد نياز خود را از بخـشهــاى انتهـاى ريشـه جـــب مسى كنـــ. بهعبارت ديخر ايسن گونـه در ناحيـه يقـه و نزديـك خــاك فاقـد

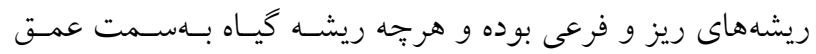
خاك نفوذ مى كند ريشه باريكتر و حالت دوكى بيدا مى كند. ايسن در حالى است كه اخر شـرايطى بــراى رشــ سـاير گونـههــا مثـل فورببها و كراسها با ريشههاى افشان فراهم باشد ايسن كونـههـا

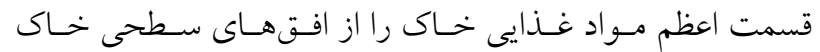
مى گيرند و تنها مواد غذايى كه آبشويى مىشود توسط ريشـه كمـا جذب مىشود. در اين شرايط ميزان دسترسى كما به مواد غـذايى كمتر شده و در رقابت بـا سـاير گونـههـا شكسـت مسى خـورد و

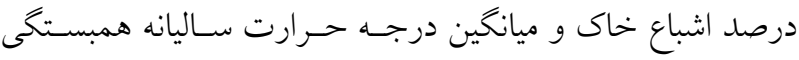
مستقيم دارد. كونه كما بهدليل داشتن ريشـههـاى قـوى و ضـخيم مىتواند شرايط سنگلاخى، خاكهاى فرسايش يافته را تحمل كند زيرا در اين شرايط احتمال حضور ساير كونـههــا كـاهش يافتـهـ و كما در رقابت با آنها موفقتر است. البته در منطقه مطالعاتى بافـت با ميزان سيلت در منطقه مطالعـاتى داراى رونـــ تقريبـاً معكـوس است يعنى با افزايش درصد سيلت، احتمال رخداد كونـه كـاهش

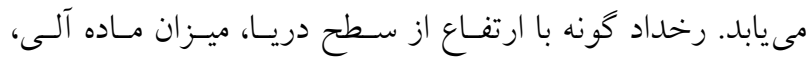

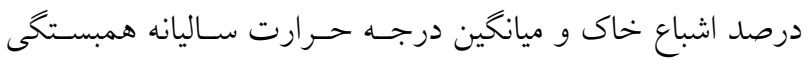
مستقيم دارد. كونه كما بهدليل داشتن ريشـههـاى قـوى و ضـخيم مىتواند شرايط سنخاخى، خاكهاى فرسايش يافته را تحمل كند زيرا در اين شرايط احتمال حضور ساير گونسههـا كـاهش يافتسه و كما در رقابت با آنها موفقتر است. البته در منطقه مطالعاتى بافـت خاى حتى در مناطق كوهستانى كه رويشگاه كونه مزبور است نيز

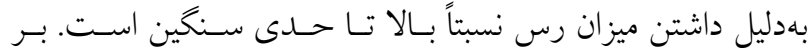
اساس مطالعه انجام شـده توسـط ايروانسى وهمكــاران مهـمتـرين 
اختيار كزاشتن عناصر نقش مهمى ايفا مى كنند. در مطالعه آزيــر و

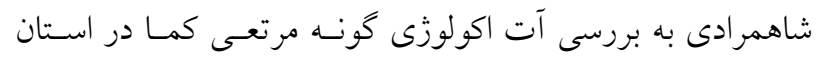

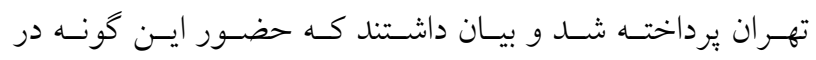

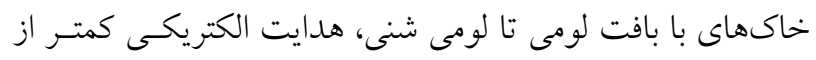

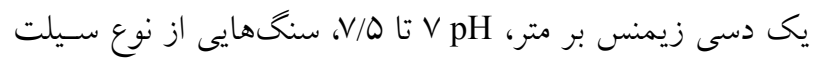

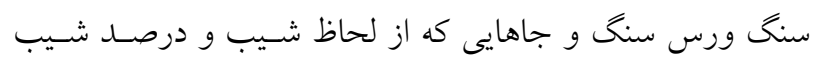

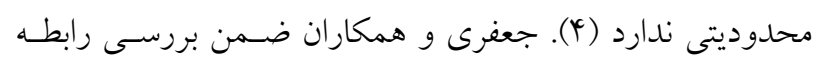

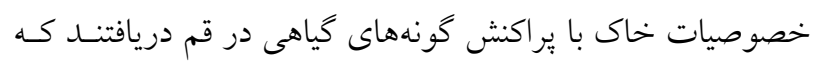

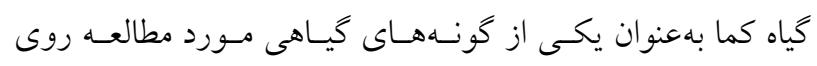

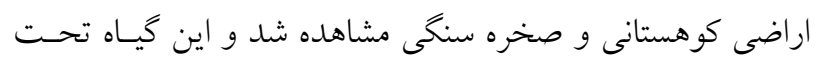

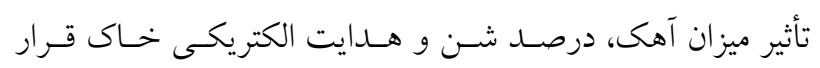

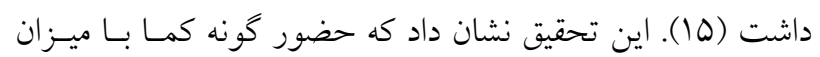

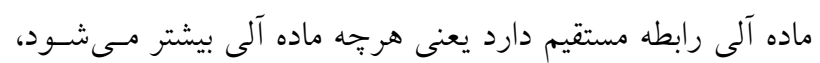

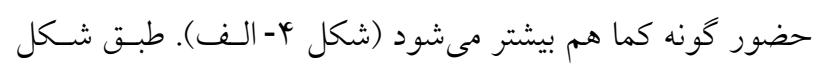

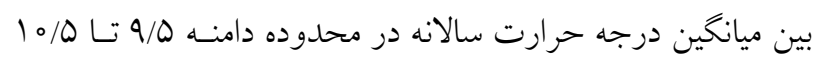

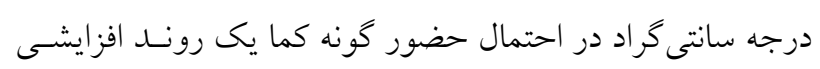

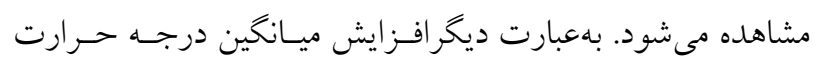

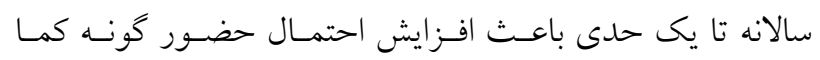
مىشود و بعد آن اثر معكوس دارد (شكل بالاع).

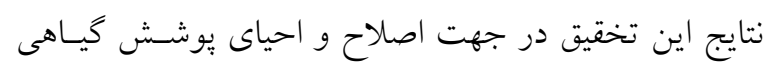

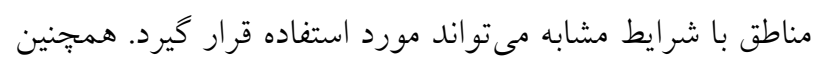

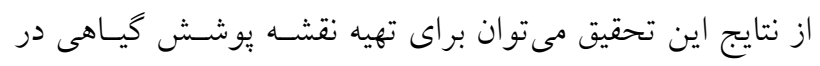

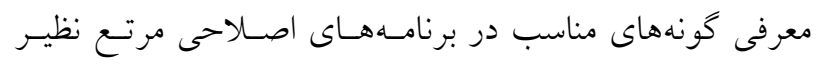

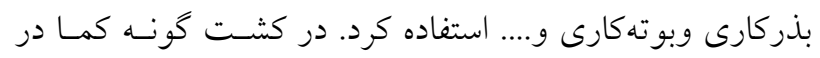
مناطق مشخص شده بهعنوان رويشكاه خوب بايد به مـواردى از

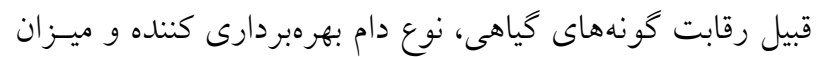

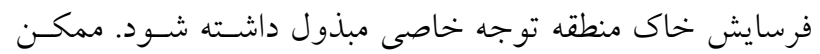

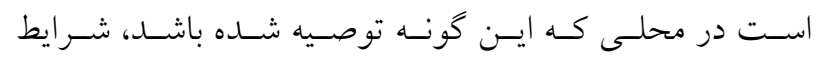

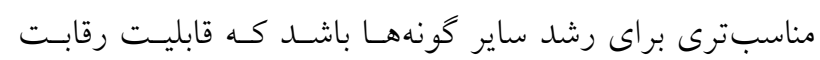

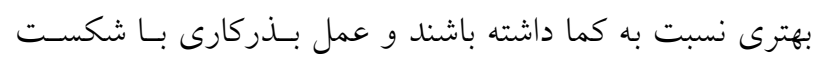

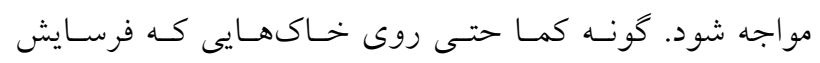

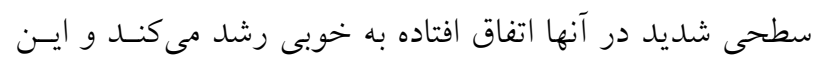

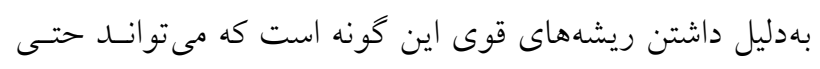

احتمال حضور آن كاهش مى يابد. درصد سـيلت خـاك بـهنهـوان

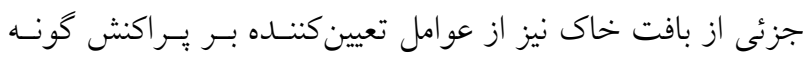

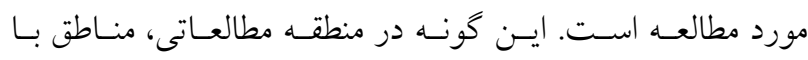

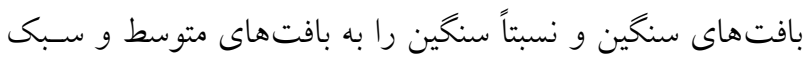

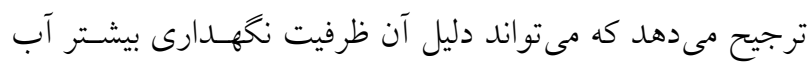

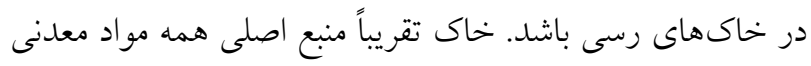

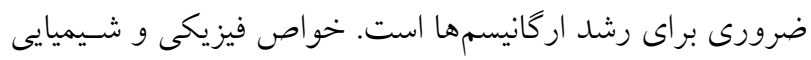

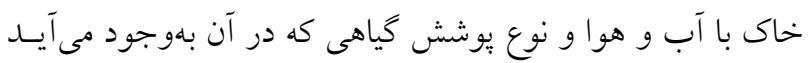

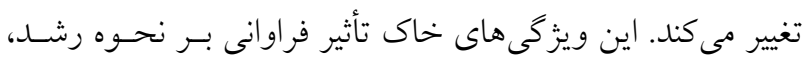

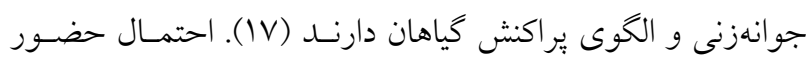

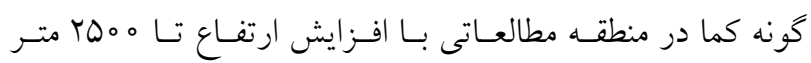

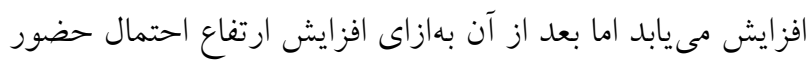

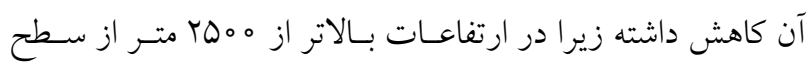

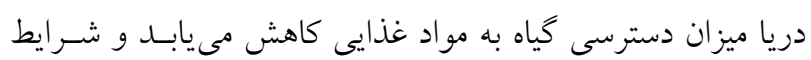

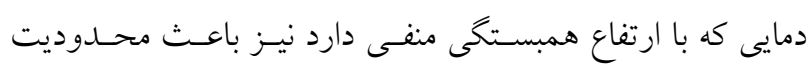

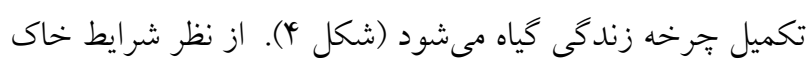

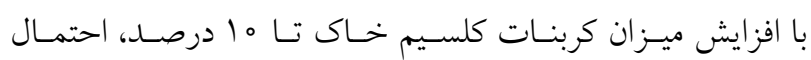

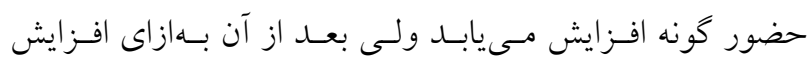

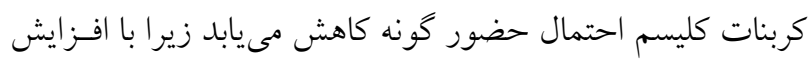

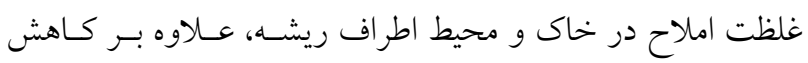

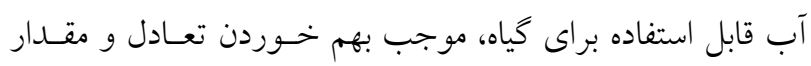

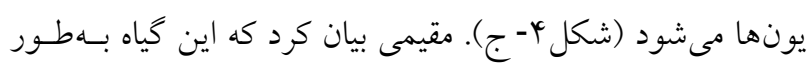

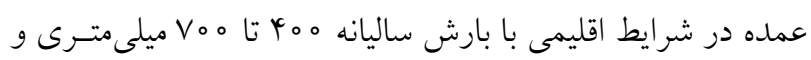

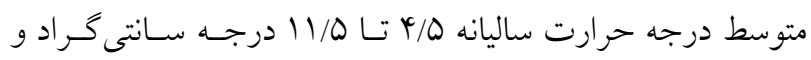

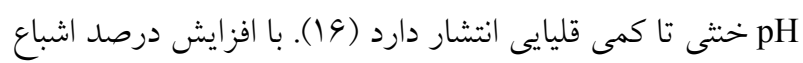

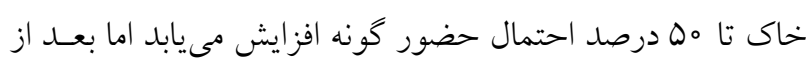

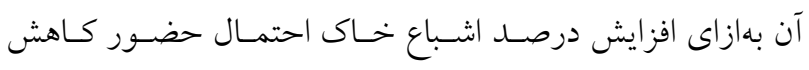

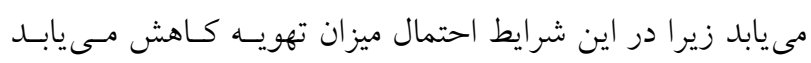

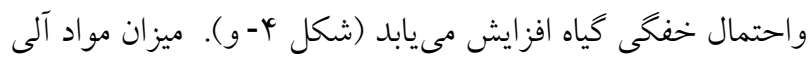

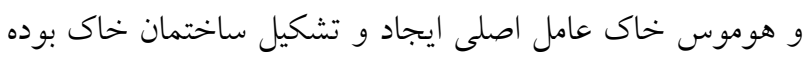

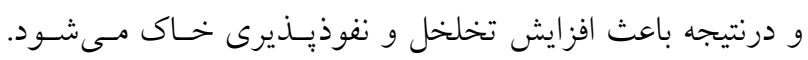

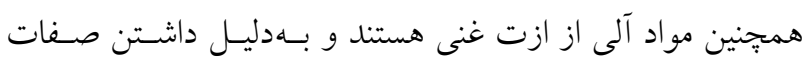

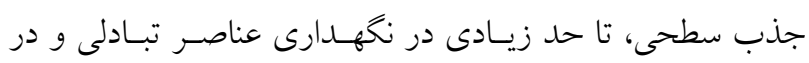




$$
\begin{aligned}
& \text { مدل، يتانسيل رويشگاه را بالا نشان دهد اما به لحاظ نوع مديريت }
\end{aligned}
$$

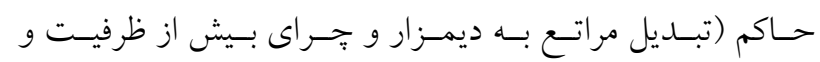

$$
\begin{aligned}
& \text { بهربردارى مفرط) شرايط براى استقرار كونه كما مناسـب نبـوده و } \\
& \text { فراوانى اين گونه در اين مناطق بالا نباشد. بايد با اعمـال مــيريت } \\
& \text { مناسب يس از كاشت بذور اجازه جوانهزنى بـهـ بــور و اسـتقرار } \\
& \text { كونه در منطقه داده شود تا در رويشـاههـاى تخريـبـيافتـه ايسن } \\
& \text { كونه تجديد حضور يابد. استفاده از روشهاى مدلسازى يراكنش }
\end{aligned}
$$

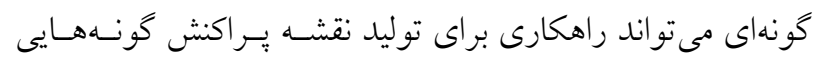

$$
\begin{aligned}
& \text { باشد كه نقشه يراكنش آنها در دسترس نبوده و اين كونههـا داراى } \\
& \text { ارزش حفاظتى، صنعتى و دارويى هستند. }
\end{aligned}
$$

$$
\begin{aligned}
& \text { شرايطى را كه خاى كاملاً افق سطحى را از دست داده را تحمل } \\
& \text { كند. اما در مناطقى كه خـاك ميـزان فرسـايش سـطحى رآن كـم آنم } \\
& \text { مىشود بهدليل ضعيف بودن در رقابت با كونههاى ديخر سـريعاً }
\end{aligned}
$$

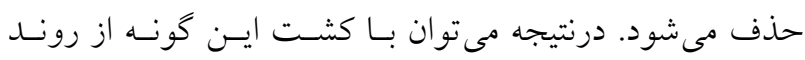

$$
\begin{aligned}
& \text { صعودى فرسايش خاى در حوضه مورد مطالعه جلو گيرى كرد. } \\
& \text { نتيجه گيرى } \\
& \text { مدل توليد شده مىتواند بهمنظور بيهنهبندى منـاطق داراى يتانسـيل } \\
& \text { حضور گونه كما استفاده شود و در برنامهاى مديريتى و حفاظتى } \\
& \text { مورد استفاده قرار گيرد. البته در برخهى منـاطق ممكـن اسـت كـهـ }
\end{aligned}
$$

\section{منابع مورد استفاده}

1. Aliakbari, A., R. Jafari, M. R. Vahabi and A. Saadatfar. 2011. Determining the potential habitat of Astragalus verus with the integration of GIS and remote sensing. Journal of Applied GIS and Remote Sensing in Natural Resources. 1: 15-27. (In Farsi).

2. Amoagheie, R. 2005. Dormancy breaking protocols for Ferula ovina. Proceedings of the Fourth International Iran \& Russia Conference, Sharekord, Iran, 709-712.

3. Ana, M., F. Becker, P. Bie, B. Hybrechts and W. Wassen. 2002. Prediction of plant species distribution in lowland river valleys in Belgium: Modeling species response to site condition. Biodiversity and Conservation 12: 2189-2216.

4. Azhir, F. and A. Shahmoradi. 2007. Autecology of Ferula ovina Boiss. in Tehran Province. Iranian Journal of Range and Desert Research 14(3): 359-367. (In Farsi).

5. Bassiri, M., A. Jalalian and M. R. Vahabi. 1989. Studies on habitat condition \& need production of native range plants in Fereydan Region. Project Report, College of Agriculture, Isfahan University of Technology, 156 p (In Farsi).

6. Beauvais, G., P. Thurston and D. Keinath. 2004. Predictive range maps for 5 species of management concern in southwestern Wyoming, Report prepared for the U.S. Geologica Survey-National Gap Analysis Program by the Wyoming Natural Diversity Database-University of Wyoming. Laramie. Wyoming. USA, 11 p.

7. Bio, A. M., P. De Becker, E. De Bie, W. Huybrechts and M. Wassen. 2002. Prediction of plant species distribution in lowland river valleys in Belgium: modelling species response to site conditions. Biodiversity and Conservation 11 (12): 2189-2216.

8. Brown, D. G. 1994. Predicting vegetation types at treeline using topography and biophysical disturbance variables. Journal of Vegetation Science 5(5): 641-656.

9. Feizi, M. T. 2013. The project of identification of ecological regions of Isfahan Province. Research Report. Research Institute of Forests and Rangelands, 261 p (In Farsi).

10. Franklin, J. 1995. Predictive vegetation mapping: geographic modeling of biospatial patterns in relation to environmental gradient. Progress in Physical Geography 19(4): 474-499.

11. Guisan, A. and N. Zimmermann. 2000. Predictive habitat distribution models in ecology. Ecological Modelling 135(2): 147-186.

12. Guisan, A. and W. Thuiller. 2005. Predicting species distribution: offering more than simple habitat models. Ecology Letters 8(9): 993-1009.

13. Hasti, T. and R. Tibshirani. 1986. Generalized additive models. Statistical Science 1(3): 297-310.

14. Iravani, M., S. J. Khajeddin and M. Bassiri. 2000. Determination of the effective environmental factors on site selection of three range species in Vahregan river basin. The 2nd National Congress and Range Management, Tehran, Iran. (In Farsi).

15. Jafari, M., M. A. Zare Chahooki, H. Azarnivand, N. Baghestani Meibodi and Gh. Zahedi. 2003. Relationships between Poshtkouh rangeland vegetation of Yazd province and soil physical and chemical characteristics using multivariate analysis methods. Iranian Journal of Natural Resources 55(3): 419-434. (In Farsi). 
16. Moghimi, J. 2005. Introduction of some important range species suitable for the development and improvement of rangelands in Iran. Technical Office of Rangeland, Arvan Publishers, Iran, Tehran. (In Farsi).

17. Nasrollahi, A. 1998. Investigating physico-chemical condition of soil characteristics to identify indicator species, MSc Thesis in Tehran University. (In Farsi).

18. Nieto-Lugilde, D., K. C. Maguire, J. L. Blois, J.W. Williams and M.C. Fitzpatrick. 2018. Multi-response algorithms for community-level modelling: Review of theory, applications, and comparison to species distribution models. Methods in Ecology and Evolution 9(4): 834-848.

19. Saki, M., M. Tarkesh, M. Bassiri and M. R. Vahabii. 2013. Application of logistic regression tree model in determining habitat distribution of Astragalus verus. Iranian Journal of Applied Ecology 1(2): 27-38. (In Farsi).

20. Tarkesh, M. and G. Jetshcke. 2012. Comparison of six correlative models in predictive vegetation mapping on a local scale. Environmental and Ecological Statistics 19(3): 437-457.

21. Vogiatzakis, I. N. 2003. GIS-based modelling and ecology: a review of tools and methods. Department of Geography, University of Reading.

22. Zaniewski, A. E., A. Lehmann and J. M. Overton. 2002. Predicting species spatial distributions using presence-only data: a case study of native NewZealand ferns. Ecological Modelling 157(2): 261-280. 


\title{
Modeling the potential habitat of Ferula ovina (Boiss) using Generalized Linear Model in Semi-Steppe rangelands of Western Isfahan
}

\author{
M. Ghazimoradi ${ }^{1}$, M. Tarkesh ${ }^{1^{*}}$ and H. Bashari ${ }^{1}$
}

(Received: March 29-2017; Accepted: May 27-2019)

\begin{abstract}
This study was aimed to predict the potential distribution of Ferula ovina (Boiss) in Feridoonshar, in the western part of Isfahan province, and to produce species response curves in relation to the environmental variables using the Generalized Linear Model (GLM). The presence and absence of the species in 278 sites (including 138 presence sites \& 140 absence sites) were collected using random stratified sampling. Digital elevation model was used to produce elevation classes, aspect and slope maps. Seventy soil profiles and 10 climate stations data were used to produce 31 environmental maps including climate and soil maps using kriging methods. According to the results, the presence of Ferula ovina was correlated with silt percent, average annual temperature, elevation, organic matter content, soil saturation percentage and $\mathrm{CaCO}_{3}$ content. The produced species distribution model had high accuracy, as indicated by calculated Kappa coefficient (0.79) and ROC area under curve plots (0.83). The result of this study can be, therefore, used in the rehabilitation and restoration of this valuable species in the rangeland ecosystems.
\end{abstract}

Keywords: Geographic information system, Interpolation, Species distribution model, Species response curve

1. Dept. of Natur. Resour., Isf. Univ. of Technol, Isfahan, Iran.

*: Corresponding Author, Email: m_tarkesh@cc.iut.ac.ir 